\title{
Critical species of Odonata in the Neotropics
}

\author{
Dennis R. Paulson \\ Slater Museum of Natural History, University of Puget Sound, Tacoma, \\ WA 98416, USA. <dpaulson@ups.edu>
}

Key words: Odonata, dragonfly, IUCN, critical species, conservation, Neotropics, South America, Middle America.

\begin{abstract}
This report summarizes progress that has been made during the past five years toward the understanding of Neotropical Odonata. It also presents a list of critical species and sites, threats to Odonata conservation in the region, and priorities for further research. This region, the richest in the world for Odonata, must be a focus of intense research and conservation efforts.
\end{abstract}

\section{REgIONAL DEFINITION}

The region is usually defined as extending from the lowlands (but not the northern highlands) of Mexico south through Central America and South America, excluding the southwestern temperate forests of Chile and Argentina (which belong to the Austral or Notogeic region), and including the islands of the Caribbean. However, for the purposes of this report it is defined as the entire region from all of Mexico south through all of South America, including the temperate zones of that region.

\section{STATE OF THE ART}

Studies on taxonomy, ecology and biodiversity

This report summarizes research published from 1999-2003, a five-year period chosen to follow that of a report submitted by the author to the Odonata Specialist Group at its 1999 meeting in Hamilton, New York. The rate of discovery of Odonata in this region continues to be high. Forty-seven new species were described from the region in 1999-2003 (Table 1), from countries that have resident odonatologists (Mexico, Venezuela, Brazil) or were visited by researchers from elsewhere (El Salvador, Colombia, Ecuador, Peru, Bolivia, Chile). This figure is slightly below the average rate of species descriptions for the past two decades. During that period, 294 species were described from the Neotropical region (Fig. 1). 
Although Figure 1 seems to indicate that the number of new species described may be declining, it is still going on at a steady pace. Furthermore, many species in collections still await description. Just during the last two years' scrutiny of specimens in my own collection, I found apparently undescribed species in at least four genera, the existence of which I had not previously suspected. In the same collection, there are $20+$ additional Neotropical species awaiting description, and I know of numerous others in all collections with sizable holdings of Neotropical material. Most taxonomists working with Neotropical collections have species waiting to be described, and new species are still discovered more rapidly than descriptions are published.

Some of these new species result from closer examination of named species and the decision that they consist of more than one species, but many of them have been first encountered in nature in recent years. Almost any extended collecting trip in the New World Tropics results in the discovery of previously unknown species. A good example comes from Venezuela. Although the odonate fauna of that country is surely the best-known in northern South America, I collected one species that appeared to be undescribed and three new records for the country during a three-week visit in December 2000 (D.R. Paulson unpubl.). Less expensive but less fun, examination of museum specimens from the Neotropics almost always produces a surprise (e.g. Paulson 2001b).

Furthermore, a month-long visit to Explorer's Inn, near Puerto Maldonado, Madre de Dios, Peru, in July 2002 added 13 species to the known fauna of that locality, already featuring the greatest diversity of Odonata at a single site of anywhere in the world (Paulson 1985; Butt 1995; D.R. Paulson unpubl.). The present list stands at 177 species, of which about 25 are still undescribed. Five species of Metaleptobasis were known from Explorer's Inn before this visit.

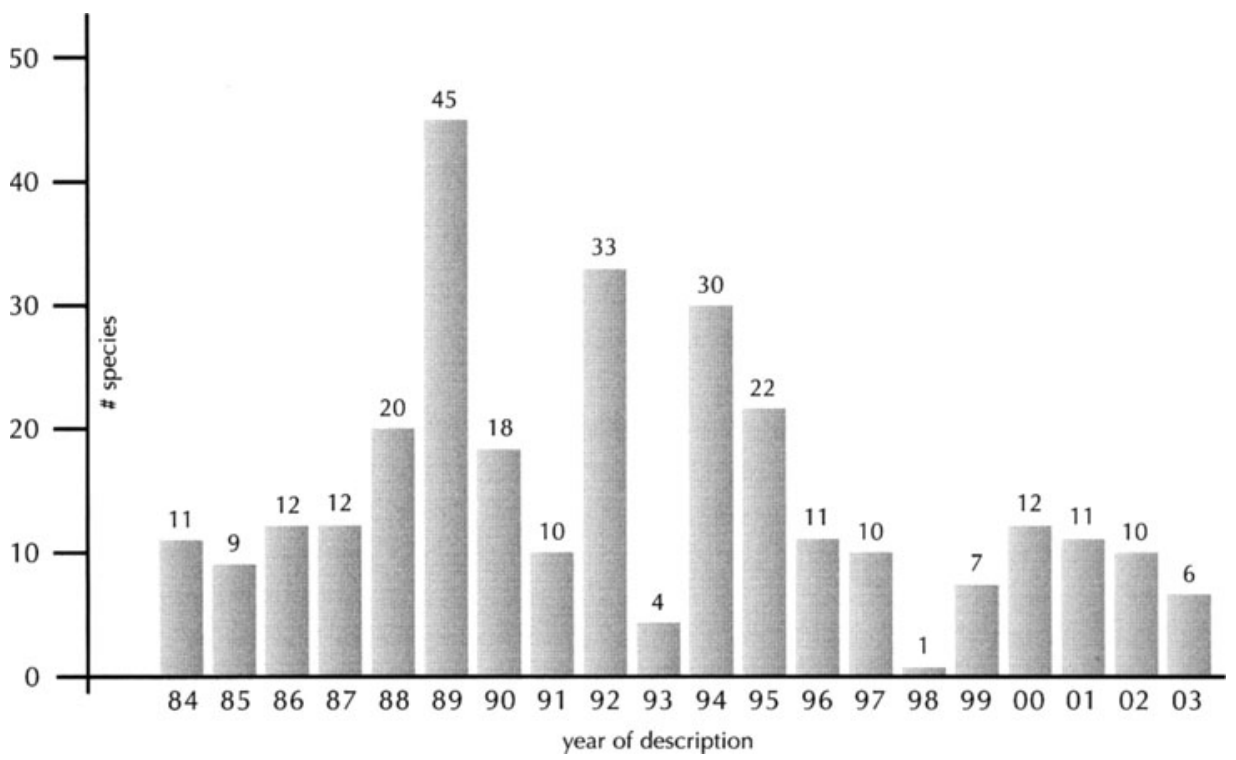

Figure 1: Odonata described from Neotropical Region, 1984 - 2003. 
I collected four species during the visit, assuming they would be among the five, but in fact two of the four had not been collected previously. I have no doubt that further visits to this locality will result in the discovery of additional species. The descriptions of larvae have always lagged behind those of adults, but in the same 1999-2003 period, the larvae of 59 Neotropical species were described (Table 2), most by the active group of researchers in Brazil. We have arrived at a time when larval descriptions are available for the majority of Neotropical genera. Although the variation within genera is still very incompletely known, it is of considerable value to be able to identify larvae to genus in ecological studies.

\section{Identification guides}

A significant milestone in the study of Neotropical Odonata was achieved with the publication in 1999 of a key to adults of all Central American species, with a slightly revised edition shortly thereafter (Förster 2001). This work will make it much easier for future workers to identify specimens collected from Guatemala to Panama and should prove useful for southernmost Mexico and northernmost Colombia.

Faunal lists

Complete lists of species published during this period treated the US Virgin Islands (Donnelly 2002), Guadeloupe and Martinique (Dommanget 2000), Costa Rica (Ramírez et al. 2000), Guyane Française (Dommanget \& Papazian 2000), Surinam (Belle 2002), and the state of São Paulo, Brazil (Carvalho 1999; Costa et al. 2000b). An update was presented on the state of Nayarit, Mexico (Paulson 2002b). Several countries have still not been surveyed sufficiently even to warrant a published list of species, and the lists of some other countries badly need updating. The very few lists of species from single localities indicate a major lack in our understanding of both biodiversity and ecological communities. Unfortunately, the small number of researchers in the region are faced with the need to describe new species and publish new records, as the bare minimum, and most of them have not found time to work out comprehensive faunal lists, with ecological notes. Fortunately, the very rich odonate fauna of lowland forests in Madre de Dios, Peru, has been the subject of intermittent but intense field work over the last quarter century (Paulson 1985, unpubl.; Butt 1995; Louton et al. 1996).

Odonata 'hotspots' are still poorly known, because so few localities have been studied in detail, but so many forest-based species, especially Zygoptera, have such restricted ranges that it is likely that a large proportion of at least the mainland Neotropics includes a series of hotspots.

Studies of individual taxa

Monographs are badly needed for many of the large genera of Neotropical Odonata. During this period, generic revisions were provided for Neoneura (Garrison 1999), Rhionaeschna (von Ellenrieder 2003a), and Triacanthagyna 
(von Ellenrieder \& Garrison 2003). Von Ellenrieder \& Muzón (1999) summarized the occurrence of Perithemis in Argentina, and von Ellenrieder (2001a) did the same for Aeshna (= Rhionaeschna) in Patagonia. Papazian (1999) discussed the six species of Calopterygidae of French Guyana. Confusion in the difficult Erythrodiplax connata group was reduced by Paulson (2003).

\section{Biology}

The number of papers on any aspect of the biology of Neotropical Odonata continues to lag well behind those on alpha taxonomy and faunal lists, and the few of any significance for the 1999-2003 period include Fincke (1999) and Melnychuk \& Srivastava (2002) on pseudostigmatid larvae, Bede et al. (2000) on the biology of an aeshnid, Rodrigues Capítulo (2000) and De Marco et al. (2002) on the biology of three libellulids, González-Soriano \& Córdoba-Aguilar (2003) on the biology of a megapodagrionid, González-Soriano (2001) on the behavior of several protoneurids, and De Marco \& Furieri (2000) on the biology of a coenagrionid. This is fewer than a dozen of the thousands of species that occur in the region. Because so little is known of the biology of the species in this region, that knowledge is not available to apply to conservation practices, and we are left only with the more general knowledge that odonate species have specific habitat needs, that we know very little about these needs for the vast majority of tropical species, and that our only recourse at this time is to attempt to preserve a wide variety of wetland habitats in every tropical region.

Table 1. New Odonata species described from the Neotropical region in 1999-2003.

\begin{tabular}{|c|c|c|}
\hline Country/species & Source & Notes \\
\hline \multicolumn{3}{|l|}{ Mexico } \\
\hline Lestes alfonsoi & González-Soriano \& Novelo-Gutiérrez (2001) & \\
\hline Leptobasis melinogaster & González-Soriano (2002) & \\
\hline Erpetogomphus erici & Novelo-Gutiérrez \& Garrison (1999) & \\
\hline Ophiogomphus purepecha & González-Soriano \& Villeda-Callejas (2000) & \\
\hline Brechmorhoga latialata & González-Soriano (1999) & \\
\hline \multicolumn{3}{|l|}{ Ecuador } \\
\hline Heteragrion cooki & Daigle \& Tennessen (2000) & \\
\hline Teinopodagrion croizati & De Marmels (2002) & \\
\hline Metaleptobasis mauffrayi & Daigle (2000) & Also Peru \\
\hline minteri & Daigle (2003) & \\
\hline Oxyagrion tennesseni & Mauffray (1999) & \\
\hline Coryphaeschna huaorania & Tennessen (2001) & \\
\hline Rhionaeschna brevicercia & Muzón \& von Ellenrieder (2001) & Also Venezuela \\
\hline Micrathyria sympriona & Tennessen (2000) & Also Peru \\
\hline Oligoclada teretidentis & Rehn (2003) & \\
\hline
\end{tabular}


Country/species Source Notes

El Salvador

Paltothemis nicolae Hellebuyck (2000)

Colombia

Cora chiribiquete Zloty \& Pritchard (2001)

Peru

\begin{tabular}{|lll|}
\hline $\begin{array}{l}\text { Polythore spaeteri } \\
\text { Rhionaeschna fissifrons }\end{array}$ Burmeister \& Börzsöny (2003) & \\
\hline \multicolumn{1}{c}{ obscura } & Muzón \& von Ellenrieder (2001) & Also Bolivia, Argentina \\
\hline Triacanthagyna williamsoni & von Ellenrieder \& Garrison (2003) & Also Bolivia \\
\hline $\begin{array}{l}\text { Brgia rosseri } \\
\text { Telebasis bickorum }\end{array}$ & Tennessen (2002) \\
\hline \multicolumn{1}{|c|}{ gigantea } & Daigle (2002b) \\
\hline
\end{tabular}

Venezuela

\begin{tabular}{|ll|}
\hline Dimeragrion clavijoi & De Marmels (1999a) \\
\hline Heteragrion palmichale & Hartung (2002) \\
\hline Rhionaeschna condor & De Marmels (2001a) \\
\hline \multicolumn{1}{c}{ demarmelsi } & von Ellenrieder (2003a) \\
\hline Sympetrum paramo & De Marmels (2001b) \\
\hline
\end{tabular}

Brazil

\begin{tabular}{|cl|}
\hline $\begin{array}{c}\text { Forcepsioneura garrisoni } \\
\text { haerteli }\end{array}$ & Lencioni (1999) \\
\hline \multicolumn{1}{|c|}{ westfalli } & Machado (2001) \\
\hline \multicolumn{1}{|c|}{ Meoneura jurzitzai } & Garrison (1999) \\
\hline \multicolumn{1}{c|}{ moorei } & Machado (2002b \\
\hline Phasmoneura janirae & Machado (2003) \\
\hline Cyanallagma angelae & Lencioni (1999) \\
\hline Oxyagrion pseudocardinale & Concioni (2001) \\
\hline \multicolumn{1}{c|}{ sulmatogrossense } & Costa et al. (2000a) \\
\hline Telebasis simulata & Tennessen (2002) \\
\hline Neuraeschna tapajonica & Machado (2002a) \\
\hline Rhionaeschna brasiliensis & von Ellenrieder \& Costa (2002) \\
\hline Lauromacromia flaviae & Machado (2002c) \\
\hline Neocordulia carlochagasi & Carvalho \& Kloosterman (2001) \\
\hline mambucabensis & Costa \& Santos (2000b) \\
\hline Santosia machadoi & Costa \& Santos (2000a) \\
\hline newtoni & Costa \& Santos (2000a) \\
\hline Rhionaeschna tinti & von Ellenrieder (2000b) \\
\hline
\end{tabular}


Table 2. Neotropical Odonata larvae described in 1999-2003.

\section{Country/species}

Mexico

\begin{tabular}{|} 
Palaemnema domina Calvert, 1903 \\
Erpetogomphus agkistrodon Garrison, 1994 \\
boa Selys, 1859 \\
cophias Selys, 1858 \\
erici Novelo, 1999 \\
ophibolus Calvert, 1905 \\
Macrothemis aurimaculata Donnelly, 1984 \\
inequiunguis Calvert, 1895 \\
Perithemis domitia (Drury, 1773 ) \\
intensa Kirby, 1889
\end{tabular}

Panama

Phyllogomphoides litoralis Belle, 1984

Venezuela

Allopetalia pustulosa Selys, 1873

Rhionaeschna condor (De Marmels, 2001)

joannisi (Martin, 1897)

vigintipunctata (Ris, 1918)

Guyane Française

\begin{tabular}{|cc|}
\hline Lauromacromia dubitalis (Fraser, 1939) & Fleck (2002) \\
\hline Argyrothemis argentea Ris, 1911 & Fleck (2003a) \\
\hline Diastatops pullata (Burmeister, 1839) & Fleck (2003b) \\
\hline Oligoclada abbreviata (Rambur, 1842) & Fleck (2003a) \\
\hline pachystigma Karsch, 1890 & Fleck (2003a) \\
\hline Orthemis aequilibris Calvert, 1909 & Fleck (2003b) \\
\hline biolleyi Calvert, 1906 & Fleck (2003b)
\end{tabular}

Brazil

\begin{tabular}{|c|c|}
\hline Heteragrion muryense & Costa \& Santos (2000) \\
\hline consors Hagen, 1862 & Costa \& Santos (1999) \\
\hline Oxyagrion basale Selys, 1876 & Costa et al. (2000a) \\
\hline haematinum Selys, 1876 & Costa et al. (2000a) \\
\hline pavidum Hagen, 1876 & Costa et al. (2000a) \\
\hline santosi Martins, 1967 & Costa et al. (2000a) \\
\hline sulinum Costa, 1978 & Costa et al. (2000a) \\
\hline Rhionaeschna brasiliensis (von Ellenrieder \& Costa, 2002) & von Ellenrieder \& Costa (2002) \\
\hline Triacanthagyna septima (Selys, 1857) & Calil \& Carvalho (1999) \\
\hline Phyllogomphoides annectens (Selys, 1869) & Costa et al. (1999b) \\
\hline Praeviogomphus proprius Belle, 1995 & Carvalho (2000) \\
\hline Aeschnosoma marizae Santos, 1981 & Costa \&Santos (2000a) \\
\hline Neocordulia androgynis (Selys, 1871) & Costa \& Santos (2000a) \\
\hline setifera (Hagen, 1871) & Costa \& Santos (2000a) \\
\hline
\end{tabular}

Novelo-Gutiérrez (2002a)

Novelo-Gutiérrez (2002c)

Novelo-Gutiérrez (2002c)

Novelo-Gutiérrez (2002a)

Novelo-Gutiérrez (2002a)

Ramírez \& Novelo-Gutiérrez (1999)

Ramírez \& Novelo-Gutiérrez (1999)

Novelo-Gutiérrez (2002c)

Novelo-Gutiérrez (2002c)

Müller \& Suhling (2001)

De Marmels (2000)

De Marmels (2001)

De Marmels (2001)

De Marmels (2001)

Fleck (2003b)

Costa \& Santos (1999)

Costa et al. (2000a)

Costa et al. (2000a)

Costa et al. (2000a)

Costa et al. (2000a)

Calil \& Carvalho (1999)

Costa et al. (1999b)

ho $(2000)$

Costa \& Santos (2000a)

Costa \& Santos (2000a)
Costa \& Santos (2000)

von Ellenrieder \& Costa (2002) 


\section{Country/species}

Brazil

\begin{tabular}{|ll|}
\hline \begin{tabular}{|l|} 
Santosia machadoi Costa \& Santos, 2000 \\
newtoni Costa \& Santos, 2000
\end{tabular} & Costa \& Santos (2000a) \\
\hline Brechmorhoga travassosi Santos, 1946 & Costa \& Santos (2000a) \\
\hline Dasythemis mincki (Karsch, 1890) & Santos and Costa (1999) \\
\hline venosa (Burmeister, 1839) & Carvalho et al. (2002) \\
\hline Diastatops intensa Montgomery, 1940 & Carvalho et al. (2002) \\
\hline Erythrodiplax basalis (Kirby, 1897) & Costa et al. (1999a) \\
\hline \multicolumn{1}{|c|}{ latimaculata Ris, 1911 } & Costa et al. (2001b) \\
\hline Iygaea Ris, 1911 & Costa et al. (2001b) \\
\hline Micrathyria longifasciata Calvert, 1909 & Costa et al. (2001b) \\
\hline spuria (Selys, 1900) & De Souza et al. (2002) \\
\hline tibialis Kirby, 1897 & De Souza et al. (2002) \\
\hline Oligoclada laetitia Ris, 1911 & De Souza et al. (2002) \\
\hline Perithemis thais Kirby, 1889 & De Souza \& Costa (2002) \\
\hline Planiplax phoenicura Ris, 1912 & De Almeida Spindola et al. (2001) \\
\hline Tramea calverti Muttkowski, 1910 & De Souza et al. (1999a) \\
\hline Argentina & De Souza et al. (1999b) \\
\hline Acanthagrion hildegarda Gloger, 1967 & \\
\hline Ischnura fluviatilis Selys, 1876 & Muzón et al. (2001) \\
\hline Rhionaeschna absoluta (Calvert, 1952) & Muzón \& von Ellenrieder (2003) \\
\hline confusa (Rambur, 1842) & von Ellenrieder (2001) \\
\hline pallipes (Fraser, 1947) \\
planaltica (Calvert, 1952) & von Ellenrieder (2001) \\
\hline Erythrodiplax nigricans (Rambur, 1842) & von Ellenrieder \& Muzón (2003) \\
\hline Perithemis icteroptera (Selys, 1857) & von Ellenrieder (1999) \\
\hline
\end{tabular}

Species assemblages (species that coexist in single habitats at single localities) are virtually unknown for Neotropical species, but von Ellenrieder (2000a) treated such assemblages at a subtropical locality in central Argentina. Rodrigues Capítulo (1999) discussed some species of Odonata as bioindicators in the Argentine pampas. Ramírez (2000) discussed the ecological distribution of cloud-forest odonates at a locality in Costa Rica, and De Marco \& Resende (2002) documented activity patterns at a locality in Brazil. Novelo-Gutiérrez et al. (2002) looked at community structure of Odonata larvae in two streams in Hidalgo, Mexico.

Regional discussions of dragonfly conservation

Two significant discussions of dragonfly conservation in the Neotropical region were published during the past two years, and both represented the first of their kind for South America. Muzón \& von Ellenrieder (1999) analyzed odonate surveys from 16 protected areas and examined the entire Argentine odonate fauna with regard to protected areas, finding that $189(72 \%)$ of the 264 species had been 
recorded in at least one protected area within the previous three years. They concluded that most of the odonates from Argentina could be categorized as 'data deficient' regarding their distribution ranges, population densities, and habitat preferences of adults and larvae. However, they suggested 13 species requiring proprietary attention, based on their restricted distribution or distribution limited to threatened areas, unusual biological traits, or taxonomic isolation.

De Marmels (1999b) evaluated rare Venezuelan Odonata for their possible inclusion in a National Red Data Book. He considered $113(23.5 \%)$ of the 480 species and subspecies of Venezuelan Odonata "rare", defined as being known from three or fewer individual records or three or fewer localities. Of these, he discussed 38 species considered at risk because they are known only from the northern and northwestern parts of the country, where the human population density is greatest and environmental threats are thus most significant. Of that list, only seven species are endemic to Venezuela and can be considered of international concern. Only a few species are known well enough that they can be considered under considerable threat.

\section{CRITICAL SPECIES}

Species red-listed by IUCN

For the Neotropics 25 species have been listed in the '2003 IUCN Red List of threatened species' (IUCN 2003) (Table 3).

All of the species listed by the IUCN (2003) are worthy of special concern, as all have relatively limited ranges and are associated with intact forest. Unfortunately, they were chosen for the most part because of a complete lack of information about their present status. Most are probably rare, just because of their limited range and their occurrence in regions with much deforestation, but some are almost surely locally common and probably not endangered if their range is included in protected areas. This is likely for at least some of the Costa Rican species, and it is even more unfortunate that we lack that information. The species considered of high conservation priority in this report (Table 4) share the limited range and forest habitat of the IUCN species but in addition are isolated taxa, often monotypic genera. Their loss is considered more significant than the loss of a species of a speciose genus such as Palaemnema or Epigomphus. All of the IUCN species could be added to the priority list, but I choose to limit it to focus more sharply on where I think future resources should be applied.

Species considered to be at risk

For the most part, it is very difficult to designate critical species for this region (Table 4). A very large number of species are known from only a few localities, many from only the type locality, and it remains to be seen if they are in fact that restricted in distribution. It is likely they are not, because the same collecting expeditions that turn up undescribed species also gather additional records of many of 
Table 3. Neotropical species red-listed by IUCN (2003). CR: critically endangered; EN: endangered; $\mathrm{VU}$ : vulnerable.

\begin{tabular}{llllll}
\hline Species & CR EN VU & Occurrence \\
\hline Amphipteryx agrioides Selys, 1853 & 0 & $\bullet$ & 0 & Belize, Colombia, El Salvador, Guatemala, \\
& & & & Honduras, Mexico (at least 3 species under \\
this name; Colombia record probably in error)
\end{tabular}

these single-locality species. Sometimes subsequent records are quite distant from first records, indicating a much larger range than might have been assumed. For example, the three known localities for Orthemis anthracina De Marmels, 1989, are far apart, in southern Venezuela (De Marmels 1989a), southern Peru (D.R. Paulson unpubl.), and Panama (R.W. Garrison pers. comm.). Yet other species do seem to be extremely restricted, as is known in better-studied areas in the West Indies, Mexico, and Central America. The rarity of species, whether real or because of data deficiency, can be illustrated easily. For example, Costa Rica has nine species of the forest-stream gomphid genus Epigomphus. Only two of them are known to occur in other Central American countries, and four of them are still known from the single localities from which they were described. Epigomphus typically have short flight periods early in the rainy season, so a temporal restriction is added to 
a spatial one, making documentation of their occurrence quite difficult. Yet one of the species, E. subobtusus Selys, 1878 , has been found in most of the countries between Guatemala and Costa Rica, at numerous localities. We know nothing that will allow us to comprehend this difference in the species. Nevertheless, there appear to be a sufficient number of range-restricted species that very many of them are threatened by even local deforestation.

\section{Monotypic genera}

Unless they are genera well removed from their nearest relatives, I attribute less significance to monotypic genera, whether restricted in range or not, than was done by Moore (1997: table 6.2). This is because the generic classification of many Neotropical odonates, especially coenagrionids, is still unsettled. For example, of those genera on Moore's list, Archaeallagma is now a synonym of Cyanallagma, and Mesamphiagrion is very close to that genus (De Marmels 1989b). Similarly, Leucobasis is very close to Leptobasis (D.R. Paulson pers. obs.), and Agnophilogenia was synonymized with Philogenia (von Ellenrieder 2003b). Some other monotypic genera have not been examined in the light of recent phylogenetic standards. However, I do consider certain species in monotypic genera with restricted range worthy of further attention (most of them have scarcely ever been seen in the field), and they are included in Table 4.

\section{Single-country endemics}

The numbers of single-country endemics in each country are listed in Table 5 . There are very many of them in the Neotropics, as the total number (648) indicates. Many of the species will surely be found in at least adjacent countries, but new species are being described about as fast as additional country records are accruing, so the number endemic to single countries will remain high. The relationship between total species and endemic species (Fig. 2) is a very strong one, but the relationship between region size and endemic species (Fig. 3) is looser, in this case because Venezuela has many endemics relative to its size because it has been much better-studied than nearby countries. On the other hand, Argentina is very large but has relatively few endemics because so much of it is in the south temperate zone, with a depauperate odonate fauna. Obviously a species can be endemic to a large country (e.g. Brazil) and still have a substantial range, but those endemic to small countries (e.g. Belize or Jamaica) by definition have a very small range.

\section{Unusual biology}

The only Neotropical species that might be considered to have unusual biology (as in Moore 1997: table 6.3) are those that breed in phytotelmata, which include the entire family Pseudostigmatidae and certain genera in the families Protoneuridae (Roppaneura), Coenagrionidae (Diceratobasis, Leptagrion), Aeshnidae (Gynacantha, Triacanthagyna), and Libellulidae (Erythrodiplax, Libellula) (Corbet 1999: 144). Other genera (Orthemis of Libellulidae, some long-bodied Coenagrionidae) will 


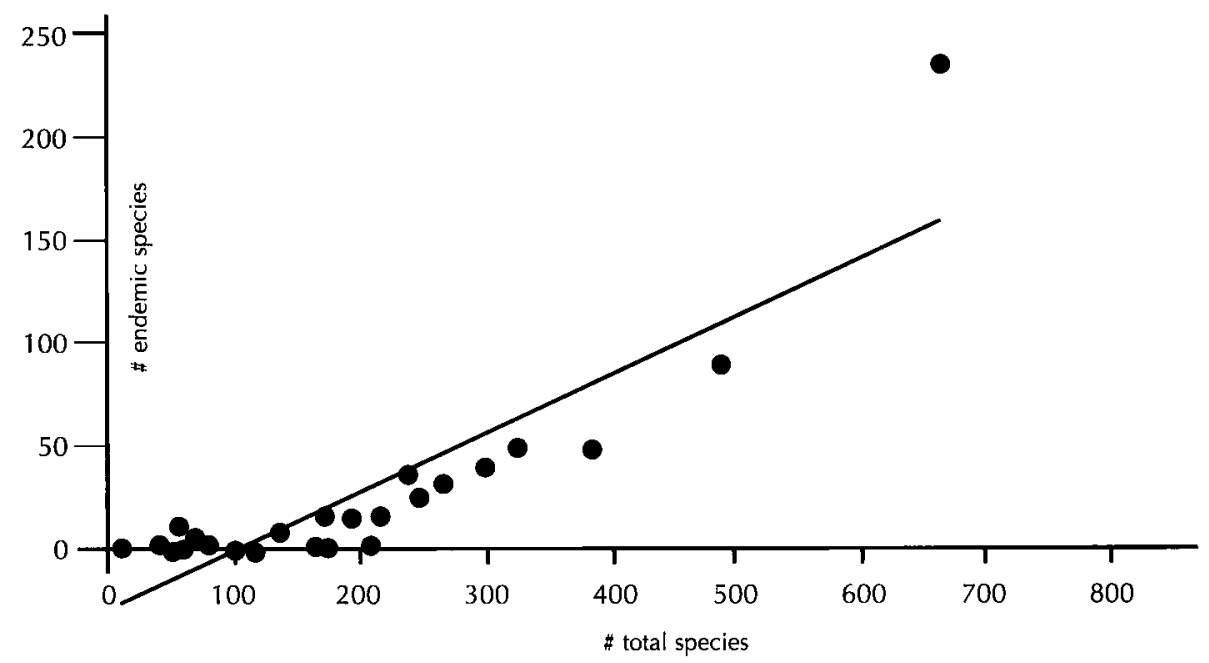

Figure 2: Relationship between endemic species and total species of Odonata in Neotropical countries; $r^{2}=0.7832$.

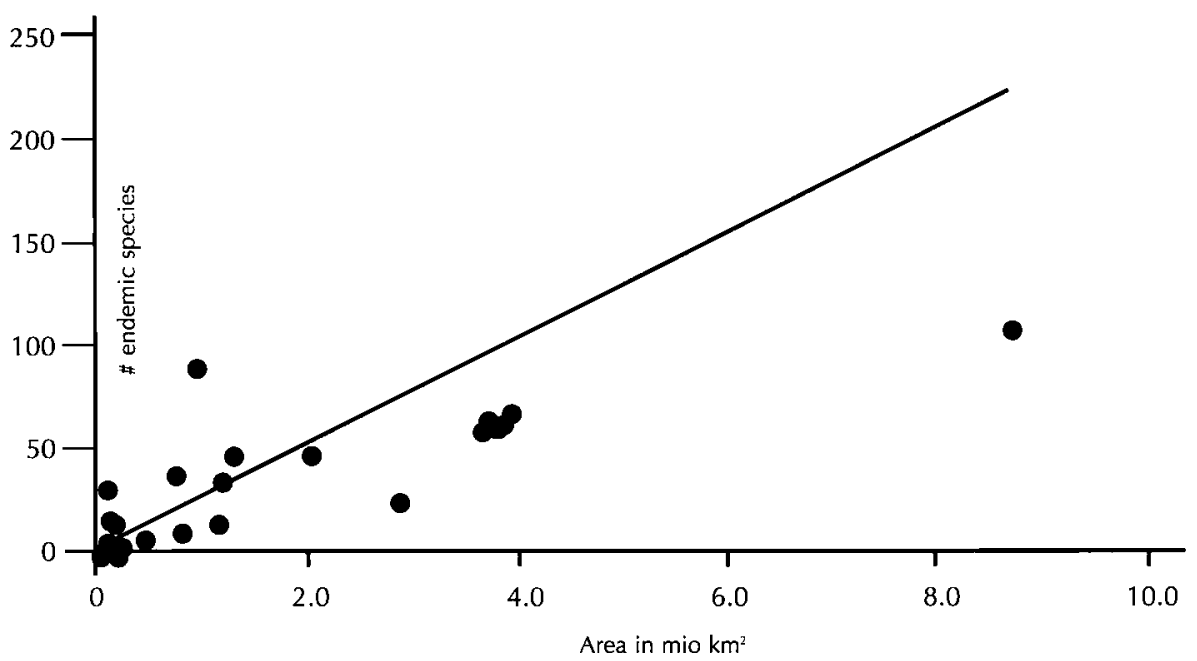

Figure 3: Relationship between endemic species and area of Neotropical countries; $r^{2}=0.8489$.

certainly be found to have species in this category. In addition, a few temperatezone species breed in semi-terrestrial habitats (Phenes raptor, Garrison \& Muzón 1995; Gomphomacromia spp., N. von Ellenrieder pers. comm.). So little is known about the biology of most Neotropical species that further studies may uncover quite extraordinary natural history. One of the largest gaps in our knowledge is how odonates of all kinds use the forest canopy. 
I am unable to recommend any actions to promote the conservation of these species, other than halting the destruction of the aquatic and terrestrial habitats that support them. Some of them surely occur within protected areas, but this is poorly known, as a good many of the occurrence records of the species are from areas outside national parks and other preserves. Fortunately, Odonata are not under threat of poaching, as are some vertebrates and, locally, butterflies. So if sufficient tracts of their habitats are preserved in something like their present condition, so will be these species be preserved.

\section{CRITICAl Sites AND THREATS}

There is no critical 'site' as such, but there are regions that either have a large number of special species and/or are especially threatened by habitat destruction, the primary factor in odonate population declines.

The Caribbean islands are the source of many species of concern, because the restricted nature of the distribution of these species is undoubted, given the size of the islands and the extent of available habitat for them. All of the West Indies are heavily populated, and, although some of the islands are less degraded than others, probably all species endemic to single islands (Cuba, Hispaniola, or Jamaica) are greatly. at risk, and have so been indicated here (Table 4). Species that occur on two or more islands have not been listed, although some of them are almost as much at risk. Of this archipelago, only Cuba has resident odonatologists, and they are unable to carry out the searches necessary to determine the status of the endemic species there. The mountains of Hispaniola are of special importance because of the presence of the only synlestid in the New World.

The Chiriqui Highlands and surrounding lowlands of Costa Rica and Panama represent another critical area, the home of the distinctive Thaumatoneura inopinata and numerous stream-dwelling odonates that occur nowhere else (Ramírez et al. 2000).

Another special area because of its high degree of endemism is Pantepui, the series of granitic mountains rising from the plains of southern Venezuela and surrounding countries. The taxonomically isolated species of this region are considered of special significance, but there are also numerous endemics of common genera. This region is much less threatened by habitat degradation than the West Indies and other more heavily populated Neotropical areas. Although not tropical, many of the Odonata endemic to the subantarctic forests of Argentina and Chile are taxonomically isolated or have unusual biological traits, and that region is of great significance. The streams inhabited by many of the endemic species are severely affected by introduced salmonid fishes and forest clearing, among other factors (Carle 1996).

Importantly, all of these areas are centers of endemism of vertebrates, so their importance to biodiversity has been much publicized. Environmental threats remain the same as in previous years. The only one that becomes ever more acute 
Table 4. Neotropical Odonata species considered of priority for conservation efforts. DD: data deficient, might have to be deleted from list with increasing survey efforts; RR: range restricted; IT: isolated taxon.

\section{Family/species}

Amphipterygidae

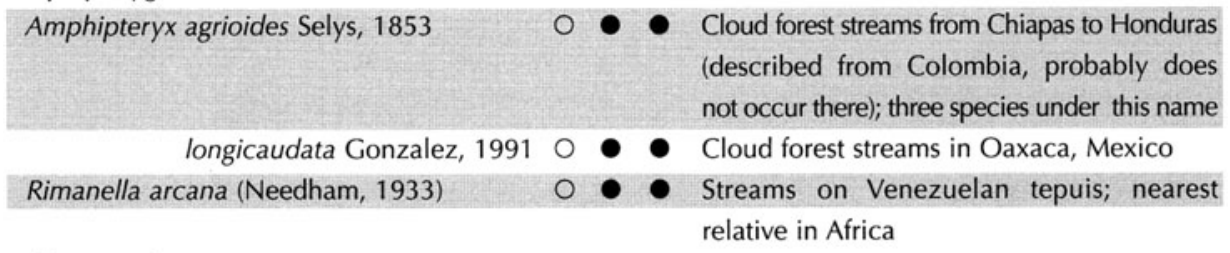

Calopterygidae

Iridictyon myersi Needham \& Fisher, 1940

trebbaui Rácenis, 1968

- Streams on Venezuelan tepuis; nearest relatives in Africa

Dicteriadidae

Dicterias atrosanguinea Selys, 1853

- Rain forest streams in Brazil; family has no near relatives; other species in family Heliocharis amazona Selys, 1853, very widespread

Polythoridae

Chalcothore montgomeryi (Rácenis, 1968)

Kalocora aurea Ris, 1918

Stenocora percornuta Kennedy, 1941

Synlestidae

Phylolestes ethelae Christiansen, 1948

- Mountain streams in Hispaniola; nearest relatives in Africa, Australia

Megapodagrionidae

Hypolestes clara (Calvert, 1891)

trinitatis (Gundlach, 1888)

Mesagrion leucorrhinum Selys, 1885

Neuragrion mysticum Karsch, 1891

Sciotropis cyclanthorum Rácenis, 1959

lattkei De Marmels, 1994

Coenagrionidae

$\begin{array}{lllll}\text { Diceratobasis macrogaster (Selys in Sagra, 1857) } & 0 & - & 0 & \text { Bromeliads in forest in Jamaica } \\ \text { melanogaster Garrison, 1986 } & \bigcirc & - & \circ & \text { Bromeliads in forest in Hispaniola } \\ \text { Enallagma truncatum (Gundlach, 1888) } & - & 0 & \text { Ponds in Cuba; rare } \\ \text { Hylaeonympha magoi Rácenis, } 1968 & \text { - } & \text { - } & \text { Habitat? in Venezuela; monotypic genus }\end{array}$




\section{Family/species}

Thaumatoneuridae

Thaumatoneura inopinata McLachlan, 1897

Protoneuridae

\begin{tabular}{|c|c|c|c|c|}
\hline Junix elumbis Rácenis, 1968 & 0 & ○ & ○ & Forest streams in Venezuela; monotypic genus \\
\hline Microneura caligata Hagen in Selys, 1886 & 0 & $\bullet$ & 0 & Forest streams in Cuba; monotypic genus \\
\hline Neoneura carnatica Selys, 1886 & 0 & - & 0 & Forest streams in Cuba \\
\hline maria (Scudder, 1866) & 0 & $\bullet$ & 0 & Forest streams in Cuba \\
\hline Proneura prolongata Selys, 1889 & $\bullet$ & - & - & $\begin{array}{l}\text { Probably forest streams in Peru; monotypic } \\
\text { genus }\end{array}$ \\
\hline Protoneura capillaris (Rambur, 1842) & O & ○ & O & Forest streams in Cuba \\
\hline dunklei Daigle, 1990 & 0 & ○ & 0 & Forest streams in Hispaniola \\
\hline sanguinipes Westfall, 1987 & $\mathrm{O}$ & ○ & O & Forest streams in Hispaniola \\
\hline
\end{tabular}

Pseudostigmatidae

$\begin{array}{cccccc}\text { Mecistogaster amalia (Burmeister, 1839) } & \bigcirc & - & 0 & \text { Rain forests on Atlantic coast of Brazil } \\ \text { asticta Selys, 1860 } & \bigcirc & - & \bigcirc & \text { Rain forests on Atlantic coast of Brazil } \\ \text { pronoti Sjöstedt, 1918 } & \bigcirc & - & \bigcirc & \text { Rain forests on Atlantic coast of Brazil }\end{array}$

Petaluridae

Phenes raptor Rambur, 1842

- Temperate streams in Chile and Argentina; relict, nearest relatives in Australia and New Zealand

Austropetaliidae

Hypopetalia pestilens McLachlan, 1870

Phyllopetalia apicalis Selys, 1858

apollo Selys, 1878

- Temperate streams in Chile; relict, family also in Australia

pudu Dunkle, 1985

- Temperate streams in Chile and Argentina; relict, family also in Australia

stictica Hagen in Selys, 1858

- Temperate streams in Chile and Argentina; relict, family also in Australia

Aeshnidae

Aeshna williamsoniana Calvert, 1905

- 0

- Highland streams in Mexico, Costa Rica, Panama; very seldom encountered; probably does not belong in this genus

\section{Gomphidae}

Progomphus serenus Hagen, 1878 tennesseni Daigle, 1996

○

$\mathrm{O}$ zephyrus Needham, 1941

O

Neopetaliidae

Neopetalia punctata (Hagen in Selys, 1854)

Libellulidae

Erythrodiplax bromeliicola Westfall, 2000 Nothodiplax dendrophila Belle, 1984
- 0 Bromeliads in forests of Cuba and Jamaica; rare

- Habitat? in Surinam; monotypic genus 
is habitat destruction, as primary forests are cut at a high rate throughout the region. Costa Rica presents an interesting example. Much effort is being put forth in an attempt to conserve its biodiversity, but it is clear that in the near future there will be little in the way of natural habitats left except in official preserves. When I lived there in 1966-1967, there were many stream crossings that had some remnant forest along them, and I have been told by others that this is becoming rarer and rarer. In my experience, when the forest disappears from a stream, so do many of the odonate species, even if the aquatic habitat remains suitable. Although without quantitative data, it is common knowledge among those who study tropical odonates that the upland vegetation is just as crucial as the aquatic situation.

The effects of global warming are being reported for odonate species and communities. At this time these changes appear to be more in the area of opportunities (many range expansions, Ott 2001) than constraints, but the composition of odonate communities will change as new species are added to them, and the effects of competition in these new mixes can only be speculative at this time. It is quite apparent that Neotropical species are expanding their ranges rapidly into and within the United States (Behrstock 2000; Paulson 2001a), but there is no such information about effects of this phenomenon on odonate populations at the other end of the tropics in the southern hemisphere or within tropical latitudes.

Our knowledge base is still insufficient to pin down very many critical sites. At each site studied, there is a different fauna, often including species known so far only from that site. For example, sites not too distant from one another in Peru are sufficiently well known to allow comparisons. The faunas of Explorer's Inn and Pakitza, of similar elevation in lowland rain forest and about $200 \mathrm{~km}$ apart in southern Peru, have fewer than one-fourth of their species in common (overlap 23\%). Three sites (Explorama Inn, Explorama Lodge, Explornapo Camp) in northern Peru are closer together and more similar (Dunkle 1989, and pers. comm.); faunal overlap when comparing pairs of sites ranged from $33-46 \%$.

\section{CONSERVATION PRIORITIES AND RECOMMENDATIONS}

This could be the most important part of my report, but it is the most difficult section to produce, as we know so little detail about the situation in any country. Much guesswork went into my 1999 report to the Odonata Specialist Group on Costa Rica (D.R. Paulson unpubl.), a relatively well-known country with many protected areas and of great familiarity to me. A much greater degree of guesswork would be necessary anywhere else, with the possible exception of Belize or a few other similarly small regions. The published records of Neotropical Odonata are so inadequate relative to their actual distribution that records are lacking from many countries where the species surely occur.

On a finer level, i.e., distribution relative to protected areas, we remain in the Dark Ages over the vast majority of tropical America. A large number of species are known from only one or a few localities, and some of them may indeed be very limited in distribution, but there have been many occasions when the second 
locality known for a species was in a second country. Thus much more field work will be necessary to establish just how restricted many species are. However, for practical purposes, any species that is apparently restricted may have to be treated as such when making conservation decisions.

In summary, we are still (a) slowly learning more about Neotropical Odonata, and (b) almost surely losing species to extinction in countries that are undergoing rapid deforestation. The simple solution, if we could apply it, would be to increase the rate of (a) and decrease the rate of (b).

Table 5. Total number of species and number of endemic species presently recorded from Neotropical countries and island groups.

\begin{tabular}{|c|c|c|c|}
\hline Country & Total spp. & Endemic spp. & Area $\mathbf{k m}^{2}$ \\
\hline Mexico & 324 & 48 & $1,972,564$ \\
\hline Guatemala & 205 & 3 & 108,889 \\
\hline Belize & 172 & 2 & 22,965 \\
\hline El Salvador & 82 & 1 & 21,041 \\
\hline Honduras & 163 & 1 & 112,492 \\
\hline Nicaragua & 98 & 1 & 120,254 \\
\hline Costa Rica & 265 & 32 & 51,100 \\
\hline Panama & 214 & 17 & 75,517 \\
\hline Colombia & 237 & 36 & $1,141,748$ \\
\hline Ecuador & 300 & 40 & 272,045 \\
\hline Peru & 384 & 48 & $1,285,216$ \\
\hline Bolivia & 171 & 15 & $1,098,581$ \\
\hline Venezuela & 489 & 90 & 912,050 \\
\hline Trinidad & 114 & $\mathbf{0}$ & 5,128 \\
\hline Guyana & 162 & 4 & 214,969 \\
\hline Surinam & 192 & 16 & 163,265 \\
\hline Guyane Française & 158 & 2 & 83,534 \\
\hline Brazil & 667 & 233 & $8,547,404$ \\
\hline Paraguay & 133 & 8 & 406,752 \\
\hline Uruguay & 52 & 0 & 176,215 \\
\hline Argentina & 246 & 26 & $2,780,400$ \\
\hline Chile & 54 & 11 & 756,096 \\
\hline Cuba & 80 & 5 & 110,860 \\
\hline Hispaniola & 64 & 7 & 27,755 \\
\hline Jamaica & 57 & 1 & 10,991 \\
\hline Puerto Rico & 49 & 0 & 8,959 \\
\hline Lesser Antilles & 39 & 3 & 6,300 \\
\hline Galapagos & 8 & 1 & 7,844 \\
\hline Total & & 651 & \\
\hline
\end{tabular}




\section{RESEARCH PRIORITIES}

Research priorities must remain at least threefold:

(1) Continue to describe undescribed species and prepare generic monographs of Neotropical groups.

(2) Perhaps even more important, conduct many more faunal studies to gain a better understanding of alpha diversity at additional sites. There are still only a handful of sites through the entire Neotropical region for which the odonate fauna is even moderately well known (Table 6).

(3) Conduct field research to study unusual species, especially taxonomic outliers.

We know essentially nothing about the biology of entire families of South American odonates, for example Dicteriadidae, Perilestidae, Neopetaliidae, and Austropetaliidae, and know other moderately speciose families such as Platystictidae and Protoneuridae through studies of only a few species at best.

Much can be contributed by careful observation and field notes, even if specific research studies are not conducted. Collectors should spend at least some time observing and note-taking to supplement their collections of interesting (or even common) species. Field collections should be accompanied by photos or color descriptions in life, something sadly lacking for the majority of Neotropical species.

One very important long-term goal should be to get specimen records in databases. There are tens of thousands of Neotropical specimens in collections, and to have instant access to all these records would be a tremendous asset to taxonomy, biodiversity, and conservation. More and more vertebrate collections are accessible in this way, and the order Odonata would be one of the most manageable taxa to start the same process for the invertebrates. At present there are not even inventories available for the great majority of collections.

\section{Current activities}

\section{Current research}

My own current research is heavily oriented toward Neotropical odonates. I intend to describe or have others describe the 20-25 undescribed species known from Tambopata National Reserve and Bahuaja-Sonene National Park, in Peru. I plan to update the faunal list from the area, especially Explorer's Inn, to re-emphasize its importance to conservation of biodiversity. A month-long visit to the area in July 2002 allowed me to gather much more information on the natural history of the Odonata of that very rich area, and I have put together a notebook with field keys and illustrations of scanned specimens to facilitate odonate work by anyone who visits there. The Neotropical countries have as many researchers now as they have ever had, but more of them are residents. Brazil is especially rich in odonatologists, Federico Lencioni, Angelo Machado, Janira Martins Costa, and others, but they are spread over a huge area. Javier Muzón and Natalia von Ellenrieder 
have been active in Argentina, Jürg De Marmels in Venezuela, Carlos Esquivel and Alonso Ramírez in Costa Rica, Jean-Michel Maes in Nicaragua, and Enrique González and Rodolfo Novelo in Mexico.

North American odonatologists - Ken Tennessen, Jerrell Daigle, Bill Mauffray, Steve Valley, and Jim Johnson - have been surveying parts of both Ecuador and Bolivia in recent years, finding many undescribed species (see Table 1) and adding much to our limited information about distribution and habitat preference of many species. They have not spent sufficient time at any one locale to contribute a meaningful faunal list, however. European workers have also studied odonates in Latin America in recent years, Graham Vick and David Chelmick in Brazil (Vick \& Chelmick 2001), Günther Peters in Mexico and Cuba (Peters 1988), and Göran Sahlén and students in Costa Rica (Hedström \& Sahlén 2003).

\section{Current conservation and education}

To my knowledge, there are no in-country conservation programs or programs to educate about conservation that involve Odonata in the Neotropical region at present. Conserving habitats for vertebrates, which has been a moderately successful activity, will help odonates as long as there are freshwater wetlands involved. Other than research, my activities toward Neotropical odonate conservation lie in the area of making information available (= education). I have placed photos in life of Neotropical species on the World Wide Web and worked with David Wagner and Piotr Naskrecki in constructing a website to facilitate identification of odonates of La Selva, Costa Rica <http://ghostmoth.eeb.uconn.edu/laselvadragons/>. I have also placed scans of specimens of almost 300 Neotropical species <http://www.ups.edu/biology/museum/NeotropOdonata.html> on the web.

Beyond the preservation of natural habitats, what are badly needed for Latin America are (1) guide books to the odonate faunas of countries or local areas such a book to the entire region would be a monumental undertaking - and (2) programs to raise the consciousness of local people about the importance of wetlands.

The future

Much remains to be done in all of the countries in this region. Colombia especially remains terra incognita, a serious gap and a heartbreaking one, as it surely has already lost localized odonate species and still supports a large number of endemic odonates in areas that are doubtless now being logged and degraded. The political situation there makes it unlikely there will be any improvement in our knowledge base. Peru is of equal interest and should be a prime target for odonate biodiversity surveys, as it is at the very top of megadiversity countries, its political situation is presently stable, and a few parts of the country are already moderately well surveyed. Ecuador and Bolivia deserve equal attention, and even Venezuela and Argentina, the best known of the Andean countries, are not thoroughly surveyed. Farther east, the Guianas could use much more field work, although Surinam is relatively well known because of the work of D. Geijskes and J. Belle. Trinidad has been well studied (Michalski 1988), yet additional species are added to its list on 
Table 6. Neotropical localities with $>50$ Odonata species recorded. Most have been fairly well sampled. Asterisk indicates sampling over an area of $>100 \mathrm{~km}^{2}$.

\begin{tabular}{llcll} 
Country & Locality & Species & Reference \\
\hline Mexico & Tuxtlas, Veracruz* & 133 & González-Soriano (1997) \\
\hline Costa Rica & Guanacaste Nat. Park, Guanacaste* & 86 & Brooks (1989) \\
\hline Costa Rica & Hacienda Taboga, Guanacaste & 98 & D.R. Paulson unpubl. \\
\hline Costa Rica & Barranca, Puntarenas & 66 & D.R. Paulson unpubl. \\
\hline Costa Rica & Los Chiles, Heredia & 57 & D.R. Paulson unpubl. \\
\hline Costa Rica & La Selva, Heredia & 123 & D.R. Paulson, C. Esquivel, D. Wagner, \\
\hline Costa Rica & Rincón de Osa, Puntarenas & 89 & A. Ramírez unpubl. \\
\hline Panama & Barro Colorado Island, Canal Zone & 91 & May (1979) \\
\hline Venezuela & Cerro de Neblina, Amazonas* & 161 & De Marmels (1989) \\
\hline Ecuador & Limoncocha, Napo & 149 & D.R. Paulson, S.W. Dunkle unpubl. \\
\hline Peru & Explorama Inn, Loreto & 65 & S.W. Dunkle pers. comm. \\
\hline Peru & Explorama Lodge, Loreto & 100 & S.W. Dunkle pers. comm. \\
\hline Peru & Explornapo Camp, Loreto & 84 & S.W. Dunkle pers. comm. \\
\hline Peru & Pakitza, Madre de Dios & 117 & Louton et al. (1996) \\
\hline Peru & Explorer's Inn, Madre de Dios & 177 & D.R. Paulson unpubl. \\
\hline Brazil & Parque Chico Mendes, Rio de Janeiro & 64 & Costa et al. (2001a) \\
\hline Brazil & Fazenda Rancho Grande, Rondonia* & 137 & Garrison (1989) \\
\hline Argentina & Iguazú, Misiones & 107 & Jurzitza (1981) \\
\hline
\end{tabular}

every visit by a collector (e.g. Paulson 2002a). Brazil is a huge country, and parts of it have been well studied, while other parts are virtually unknown. Some of the Central American countries are scarcely known, and, although Costa Rica stands out in how well it has been surveyed, the southern Caribbean slope is still quite inadequately known. The same is true for parts of Mexico, while other parts of that country, for example the Tuxtlas (González-Soriano 1997), are very well known.

Threats to biodiversity studies

As we begin the Twenty-first Century, the study of tropical organisms may be as endangered as the organisms themselves. One developing country after another has essentially closed its doors to biodiversity studies by researchers from developed countries. It has become difficult to get collecting permits from some countries, impossible from others. Some regulations are just as onerous on resident scientists as visitors, in part because residents have the same problems conducting research but also because some of the regulations shut down the free communication that should be possible among scientists. Another aspect of this problem is apparent across a whole spectrum of countries, from least to most developed. As more and more of the landscape becomes firmly allocated on the one hand to private land - often not accessible to researchers - and on the other hand to public land that is set aside as nature 
preserves, basic biodiversity studies become more difficult because reserves are often closed to collecting, often because of perceived conflicts of interest between researchers and the general public. Studies of most insect taxa, including Odonata, are usually most effective if accompanied by collecting, even in well-known regions.

A profoundly useful service to the biodiversity community would be for an international organization to facilitate research in tropical countries. Bioprospecting for drugs (which may be appropriately considered "biopiracy") is not the same thing as the sampling of insects for taxonomic and survey purposes, and this distinction should be made clearer at official levels. Furthermore, it should be made easy in all countries for authorized researchers to carry out appropriate collecting activities in all types of preserves. Preserve managers, permitting agencies, ecotourism operators, and the public must be provided with the understanding that the collection of individuals can be one of the more important activities that lead to the more effective preservation of species.

\section{ACKNOWLEDGEMENTS}

I thank Natalia von Ellenrieder and Rosser Garrison for reviewing a draft of this paper.

\section{REFERENCES}

Bede, L.C., W. Piper, G. Peters \& A.B.M. Machado, 2000. Phenology and oviposition behaviour of Gynacantha bifida Rambur (Anisoptera: Aeshnidae). Odonatologica 29: 317-324.

Behrstock, R.A., 2000. New records of Neotropical odonates on the Upper Texas Coast with comments on recent temperature increases. Argia 12 (1): 8-11.

Belle, J., 2002. Commented checklist of the Odonata of Surinam. Odonatologica 31: 1-8.

Brooks, S.J., 1989. Odonata collected from Guanacaste National Park, Costa Rica, July 1988. Notulae Odonatologicae 3: 49-52.

Burmeister, E.-G. \& L. Börzsöny, 2003. Polythore spaeteri, spec. nov. from the Peruvian tropical rainforest (Panguana), with remarks on its ecology. Spixiana 26: 43-48.

Butt, M., 1995. Odonata collected from the Tambopata-Candamo Reserved Zone, southeastern Peru, August 1992 - January 1993. Notulae Odonatologicae 4: 93-97.

Calil, E.R. \& A.L. Carvalho, 1999. Descrições da larva de ultimo estádio e do adulto de Triacanthagyna septima (Selys, 1857) (Odonata, Aeshnidae) com notas sobre a biologia da espécie. Revista Brasileira de Entomologia 43: 73-83.

Carle, F. L., 1996. Revision of Austropetaliidae (Anisoptera: Aeshnoidea).

Odonatologica 25: 231-259.

Carvalho, A.L., 1999. Odonata. In: Brandão, C.R.F. \& E.M. Cancello (eds) "Invertebrados terrestres, vol. 5. Biodiversidade do Estado de São Paulo, Brasil: sintese do conhecimento ao final do século XX. FAPESP, São Paulo, pp. 73-79.

Carvalho, A.L., 2000. Descriptions of the last instar larva and some structures in the pharate male adult of Praeviogomphus proprius Belle, 1995, with notes on the occurrence and taxonomic status of the species (Anisoptera: Gomphidae: Octogomphinae).

Odonatologica 29: 239-246. 
Carvalho, A.L. \& R.R. Kloosterman, 2001. Descrição da larva de Neocordulia carlochagasi Santos, 1967 (Insecta, Odonata, Corduliidae). Contribuições Avulsos do Historia Natural do Brasil (Zoologia) 32: 1-5.

Carvalho, A.L., P.C. Werneck-de-Carvalho \& E.R. Calil, 2002. Description of the larvae of two species of Dasythemis Karsch, with a key to the genera of Libellulidae occurring in the states of Rio de Janeiro and São Paulo, Brazil (Anisoptera). Odonatologica 31: 23-33.

Corbet, P.S., 1999. Dragonflies: behavior and ecology of Odonata.

Cornell University Press, Ithaca.

Costa, J.M. \& T.C. Santos, 1999. Odonata da Marambaia (ilha e restinga), Rio de Janeiro, Brasil: resultado das expedições do Museu Nacional pelo conveno entre a Universidade Federal Rural do Rio de Janeiro e a Marinha do Brasil, com a descrição da larva de Heteragrion consors Hagen in Selys, 1862 (Zygoptera: Megapodagrionidae).

Contribuições do Historia Natural de Brasil (Zoologia) 5: 1-7.

Costa, J.M. \& T.C. Santos, 2000. Espécie nova de Heteragrion Selys, 1862 do estado do Rio de Janeiro, Brasil (Odonata: Zygoptera: Megapodagrionidae). Boletim do Museu Nacional do Rio de Janeiro (Nova Serie/Zoologia) 411: 1-7.

Costa, J.M. \& T.C. Santos, 2000a. Two new species of Santosia Costa \& Santos, 1992, with a description of five new corduliid larvae (Anisoptera: Corduliidae). Odonatologica 29: 95-111.

Costa, J.M. \& T.C. Santos, 2000b. Neocordulia mambucabensis spec. nov., a new dragonfly from Rio de Janeiro, Brazil (Anisoptera: Corduliidae). Odonatologica 29: 247-253.

Costa, J.M., G.M. De Souza-Franco \& A.M. Takeda, 1999a. Descrição da larva de Diastatops intensa Montgomery, 1940 e morfologia dos diferentes estádios de desenvolvimento (Odonata: Libellulidae). Boletim do Museu Nacional do Rio de Janeiro (Nova Serie/Zoologia) 410: 1-14.

Costa, J.M., T.C. Santos \& A.M. Telles, 1999b. Phyllogomphoides annectens (Selys): description of the last instar, with a key to the South American species (Anisoptera: Gomphidae).

Odonatologica 28: 79-82.

Costa, J.M., L.O. De Souza \& T.C. Santos, 2000a. Two new species of Oxyagrion Selys, 1876, with a description of five new larvae (Zygoptera: Coenagrionidae). Odonatologica 29: 1-15.

Costa, J.M., A.B.M. Machado, F.A.A. Lencioni \& T.C. Santos, 2000b. Diversidade e distribuição dos Odonata (Insecta) no estado de São Paulo, Brasil. 1. Lista da espécies e registros biblio gráficos. Publiçoes Avulsos do Museu Nacional do Rio de Janeiro 80: 3-27.

Costa, J.M., A. do Nascimento Lourenco \& L.P. Vieira, 2001a. Odonatos coletados no Parque Ecológico Municipal Chico Mendes (Unidade de Conservação Ambiental), Rio de Janeiro, Brasil. Entomologia y Vectores 8: 431-448.

Costa, J.M., L.P. Vieira \& A. do Nascimento Lourenco, 2001b. Descrição de tres larvas de Erythrodiplax Brauer, 1868, e redescrição das larvas de E. pallida (Needham, 1904) e E. umbrata (Linnaeus, 1758), com chave para identificação das larvas conhecidas das espécies brazileiras (Odonata, Libellulidae). Boletim do Museu Nacional do Rio de Janeiro (Nova Serie/Zoologia) 465: 1-16.

Daigle, J.J., 2000. Metaleptobasis mauffrayi spec. nov. from Ecuador and Peru (Zygoptera: Coenagrionidae). Odonatologica 29: 325-328.

Daigle, J.J., 2002a. Telebasis gigantea spec. nov. from Bolivia (Zygoptera: Coenagrionidae). Odonatologica 31: 73-76.

Daigle, J.J., 2002b. Telebasis bickorum spec. nov. from Bolivia (Zygoptera: Coenagrionidae). Odonatologica 31: 177-180.

Daigle, J.J., 2003. Metaleptobasis minteri spec. nov. from Ecuador (Zygoptera: Coenagrionidae). Odonatologica 32: 371-374. 
Daigle, J.J. \& K.J. Tennessen, 2000. Heteragrion cooki spec. nov. from Ecuador (Zygoptera: Megapodagrionidae). Odonatologica 29: 255-259.

De Almeida Spindola, L., L.O. De Souza \& J.M. Costa, 2001. Descrição da larva de Perithemis thais Kirby, 1889, com chave para identificação das larvas das espécies conhecidas do género citadas para o Brasil (Odonata: Libellulidae). Boletim do Museu Nacional do Rio de Janeiro (Nova Serie/Zoologia) 442: 1-8.

De Marco, P. \& K.S. Furieri, 2000. Ecology of Leptagrion perlongum Calvert, 1909: a bromeliad-dweller odonate species. Boletim do Museu de Biologia Professor Mello Leitão (Nova Serie) 11/12: 135-148.

De Marco, P. \& D.C. Resende, 2002. Activity patterns and thermoregulation in a tropical dragonfly assemblage. Odonatologica 31: 129-138.

De Marco, P., A.O. Latini \& P.H.E. Ribeiro, 2002. Behavioural ecology of Erythemis plebeja (Burmeister) at a small pond in southeastern Brazil (Anisoptera: Libellulidae). Odonatologica 31: 305-312.

De Marmels, J., 1989a. Odonata or dragonflies from Cerro de la Neblina. Academia de Ciencias Físicas, Matemáticas y Naturales, Caracas 25: 1-91.

De Marmels, J., 1989b. Notes on Acanthagrion acutum Ris, Enallagma occultum Ris and E. ovigerum Calvert (Zygoptera: Coenagrionidae). Odonatologica 18: 245-252.

De Marmels, J., 1999a. A new species of Dimeragrion Calvert 1913 from Pantepui, Venezuela (Odonata: Megapodagrionidae). Boletin de Entomológica Venezolana, Nuevo Serie 14: 27-36.

De Marmels, J., 1999b. Rare Venezuelan dragonflies (Odonata) evaluated for their possible inclusion in the National Red Data Book. International Journal of Odonatology 2: 55-67.

De Marmels, J., 2000. The larva of Allopetalia pustulosa Selys, 1873 (Anisoptera: Aeshnidae), with notes on aeshnoid evolution and biogeography. Odonatologica 29: 113-128.

De Marmels, J., 2001a. Aeshna (Hesperaeschna) condor sp. nov. from the Venezuelan Andes, with a redescription of $A$. (H.) joannisi, comments on other species, and descriptions of larvae. International Journal of Odonatology 4: 119-134.

De Marmels, J., 2001b. Sympetrum paramo sp. n. (Odonata: Libellulidae) from the Venezuelan high Andes, with a key to the species of Sympetrum Newman, 1833 found in Venezuela. Entomotropica 16: 15-19.

De Marmels, J., 2002. Phylogenetic relationships of Priscagrion Zhou \& Wilson, 2001, with a description of Teinopodagrion croizati spec. nov. from Ecuador (Zygoptera: Megapodagrionidae). Odonatologica 31: 389-394.

De Marmels, J., 2003. Lamproneura lucerna gen. nov., sp. nov. from Venezuela, and Cyanallagma ferenigrum sp. nov., a remarkable new species from Brazil (Odonata: Protoneuridae, Coenagrionidae). International Journal of Odonatology 6: 99-108.

De Souza, L.O.I. \& J.M. Costa. 2002. Descrição de tres larvas de Micrathyria Kirby, 1889, com chave para identificação das larvas conhecidas das espécies brasileiras (Odonata, Libellulidae). Arquivos Museu Nacional do Rio de Janeiro 60: 321-331.

De Souza, L.O.I., J.M. Costa \& T.C. Santos, 1999a. Description of the larva of Planiplax phoenicura Ris, from Pantanal sul-Matogrossense, Brazil (Anisoptera: Libellulidae). Odonatologica 28: 159-163. De Souza, L.O.I., J.M. Costa \& T.C. Santos, 1999b. Redescrição da larva de Tramea calverti Muttkowski, 1910, com chave para identificação das larvas conhecidas do genero (Odonata: Libellulidae). Boletim do Museu Nacional do Rio de Janeiro (Nova Serie/Zoologia) 409: 1-7.

De Souza, L.O.I., J.M. Costa \& L.A. Espindola, 2002. Description of the last instar larva of Oligoclada laetitia Ris, 1911 and comparison with other Libellulidae (Anisoptera). Odonatologica 31: 403-407. 
Dommanget, J.-L., 2000. Liste provisoire des odonates de Guadeloupe et de Martinique. Martinia 16: 134-137.

Dommanget, J.-L. \& M. Papazian, 2000. Liste provisoire des odonates de Guyane française. Martinia 16: 138-141.

Donnelly, N., 2002. Odonata of St. Thomas and St. John, Virgin Islands. Argia 14 (1): 7-9.

Dunkle, S.W., 1989. Peru. Argia Season Summary Supplement 1989: 5-6.

Fincke, O.M., 1999. Organization of predator assemblages in neotropical tree holes: effects of abiotic factors and priority. Ecological Entomology 24: 13-23.

Fleck, G., 2002. Une larve d'odonate remarquable d la Guyane française, probablement Lauromacromia dubitalis (Fraser, 1939) (Odonata, Anisoptera, "Corduliidae").

Bulletin de la Societe Entomologique de France 107: 223-230.

Fleck, G., 2003a. Contribution a la connaissance des odonates de Guyana française: les larves des genres Argyrothemis Ris, 1911 et Oligoclada Karsch, 1889 (Insecta, Odonata, Anisoptera, Libellulidae). Annalen des Naturhistorischen Museums in Wien (B) 104: 341-352.

Fleck, G., 2003b. Contribution a la connaissance des odonates de Guyana française: notes sur des larves des genres Orthemis, Diastatops et Elga (Anisoptera: Libellulidae). Odonatologica 32: 335-344.

Förster, S., 2001. The dragonflies of Central America exclusive of Mexico and the West Indies. A guide to their identification. Second edition. Odonatological Monographs 2. Gunnar Rehfeldt, Braunschweig.

Garrison, R.W., 1989. Rondonia state. Argia Season Summary Supplement 1989: 2-4.

Garrison, R.W., 1999. The genus Neoneura, with keys and description of a new species, Neoneura jurzitzai spec. nov. (Zygoptera: Protoneuridae). Odonatologica 28: 343-375.

Garrison, R.W. \& J. Muzón, 1995. Collecting down at the other "down under". Argia 7 (3): 23-26.

González-Soriano, E., 1997. Odonata. In: González Soriano, E., R. Dirzo \& R.C. Vogt (eds) "Historia natural de los Tuxtlas", Universidad Nacional Autónoma de México, Ciudad México, pp. 245-255.

González-Soriano, E., 1999. Brechmorhoga latialata spec. nov. from Mexico (Anisoptera: Libellulidae). Odonatologica 28: 83-86.

González-Soriano, E., 2001. An unusual male aggregation in the Odonata: an aerial mating swarm in Protoneura cara Calvert and notes on other Mexican Protoneuridae (Zygoptera). Odonatologica 30: 335-340.

González-Soriano, E., 2002. Leptobasis melinogaster spec. nov., a new species from Mexico (Zygoptera: Coenagrionidae). Odonatologica 31: 181-185.

González-Soriano, E. \& A. Córdoba-Aguilar. 2003. Sexual behavior in Paraphlebia quinta Calvert: male dimorphism and a possible example of female control (Zygoptera: Megapodagrionidae). Odonatologica 32: 345-353.

González-Soriano, E. \& M. Del Pilar Villeda-Callejas, 2000. Ophiogomphus purepecha spec. nov. from Mexico (Anisoptera: Gomphidae). Odonatologica 29: 261-266.

González-Soriano, E. \& R. Novelo-Gutiérrez, 2001. Lestes alfonsoi spec. nov., a new damselfly from Mexico (Zygoptera: Lestidae). Odonatologica 30: 441-444.

Hartung, M., 2002. Heteragrion palmichale spec. nov., a new damselfly from the Cordillera de la Costa, Venezuela (Zygoptera: Megapodagrionidae). Odonatologica 31: 187-191.

Hedström, I. \& G. Sahlén, 2003. An extended description of the larva of Megaloprepus caerulatus from Costa Rica (Odonata: Pseudostigmatidae). International Journal of Odonatology 6: 23-31.

Hellebuyck, V.J., 2002. Paltothemis nicolae, spec. nov., a new dragonfly from El Salvador (Odonata: Libellulidae). Revista Nicaraguense de Entomología 59/62: 5-15. 
IUCN, 2003. 2003 IUCN Red List of threatened species. <www.redlist.org/>.

Jurzitza, G., 1981. Lista provisional de los odonatos del Parque Nacional Iguazú, Provincia de Misiones, Republica Argentina. Notulae Odonatologicae 1: 117-118.

Lencioni, F.A.A., 1999. The genus Phasmoneura, with description of Forcepsioneura gen. nov. and two new species (Zygoptera: Protoneuridae). Odonatologica 28: 127-137.

Lencioni, F.A.A., 2001. Cyanallagma angelae spec. nov. and a key to the non-Andean species of Cyanallagma (Zygoptera: Coenagrionidae). Odonatologica 30: 345-350.

Louton, J.A., R.W. Garrison \& O.S. Flint, 1996. The Odonata of Parque Nacional Manu, Madre de Dios, Peru; natural history, species richness and comparison with other Peruvian sites. In: Wilson, D.E. \& A. Sandoval (eds) "Manu: the biodiversity of southeastern Peru", Office of Biodiversity Programs, National Museum of Natural History, Smithsonian Institution, Washington, D.C., pp. 431-449.

Machado, A.B.M., 2000. Studies on Neotropical Protoneuridae. 10. Forcepsioneura lucia sp. n. from Parque Estadual Rola Moça, Minas Gerais, Brazil (Odonata, Zygoptera). Boletim do Museu Biologia Professor Mello-Leitão (Nova Serie) 11/12: 127-134.

Machado, A.B.M., 2001. Studies on Neotropical Protoneuridae. 11. Two new species of Forcepsioneura lencioni (Odonata: Zygoptera) with a key to males of the genus.

Revista Brasileira de Zoologia 18: 845-854.

Machado, A.B.M., 2002a. Neuraeschna tapajonica sp. n. from the Amazonian region of Brazil (Odonata: Aeshnidae). Lundiana 3: 29-30.

Machado, A.B.M., 2002b. Neoneura lucas spec. nov. from Brazilian Pantanal (Zygoptera: Protoneuridae). Odonatologica 31: 199-204.

Machado, A.B.M., 2002c. Description of Lauromacromia flaviae spec. nov., with notes on the holotype of L. Luismoojeni (Santos) (Anisoptera: Corduliidae). Odonatologica 31: 313-318.

Machado, A.B.M. 2003. Neoneura moorei spec. nov. from the Amazonian region of Brazil (Zygoptera: Protoneuridae). Odonatologica 32: 89-93.

Mauffray, W.F., 1999. Oxyagrion tennesseni spec. nov. from Ecuador (Zygoptera: Coenagrionidae). Odonatologica 28: 165-170.

May, M.L., 1979. Lista preliminar de nombre y clave para identificar los Odonata (caballitos) de la Isla de Barro Colorado. Cuadernos de Ciencias No. 1, Smithsonian Tropical Research Institute \& La Editorial Universitaria, Panama.

Melnychuk, M.C. \& D.S. Srivastava, 2002. Abundance and vertical distribution of a bromeliaddwelling zygopteran larva, Mecistogaster modesta, in a Costa Rican rainforest (Odonata: Pseudostigmatidae). International Journal of Odonatology 5: 81-97.

Michalski, J., 1988. A catalogue and guide to the dragonflies of Trinidad (order Odonata). Occasional Papers No. 6, Zoology Department, University of the West Indies,

St. Augustine, Trinidad.

Moore, N.W., 1997. Dragonflies - status survey and conservation plan.

IUCN/SSC Odonata Specialist Group. IUCN, Gland \& Cambridge.

Müller, O. \& F. Suhling, 2001. Phyllogomphoides litoralis Belle: description of the final instar larva (Anisoptera: Gomphidae). Odonatologica 30: 451-456.

Muzón, J. \& N. von Ellenrieder, 1999. Status and distribution of Odonata (Insecta) within natural protected areas in Argentina. Biogeographica 75: 119-128.

Muzón, J. \& N. von Ellenrieder, 2001. Revision of the subgenus Marmaraeschna (Odonata: Aeshnidae). International Journal of Odonatology 4: 135-166.

Muzón, J. \& N. von Ellenrieder, 2003. Description of the last larval instar of Ischnura fluviatilis Selys (Zygoptera: Coenagrionidae). Bulletin of American Odonatology 7: 57-60. 
Muzón, J., N. von Ellenrieder \& P. Pessacq, 2001. Description of the last larval instar of Acanthagrion hildegarda Gloger, 1967 (Odonata: Coenagrionidae).

Revista de la Sociedad entomológica Argentina 60: 95-98.

Novelo-Gutiérrez, R., 2002a. Larvae of the ophibolus-species group of Erpetogomphus Hagen in Selys from Mexico and Central America (Anisoptera: Gomphidae). Odonatologica 31: 35-46. Novelo-Gutiérrez, R., 2002b. Descripción de las larvas de Perithemis intensa Kirby, 1889 y $P$. domitia (Drury, 1773), con notas sobre otras larvas del género en México (Odonata: Anisoptera: Libellulidae). Folia Entomológica Mexicana 41: 321-327.

Novelo-Gutiérrez, R., 2002c. Two new Mexican larvae of the genus Erpetogomphus Hagen in Selys (Odonata: Gomphidae). Journal of the New York Entomological Society 110: 370-375.

Novelo-Gutiérrez, R. \& R.W. Garrison, 1999. Erpetogomphus erici spec. nov. from Mexico, and a description of the male of E. agkistrodon Garrison (Anisoptera: Gomphidae).

Odonatologica 28: 171-179.

Novelo-Gutiérrez, R., J.A. Gómez-Anaya \& R. Arce-Pérez, 2002. Community structure of Odonata larvae in two streams in Zimapan, Hidalgo, Mexico. Odonatologica 31: 273-286.

Ott, J., 2001. Expansion of Mediterranean Odonata in Germany and Europe: consequences of climate changes. In: Walther, G.-R., C.A. Burga \& P.J. Edwards (eds) "'Fingerprints' of climate change: adapted behaviour and shifted species ranges", Kluwer/Plenum, New York, pp. 89-111.

Papazian, M., 1999. Les odonates de Guyane française. 1. Les Calopterygidae (Odonata, Zygoptera). Entomologiste 55: 235-239.

Paulson, D.R., 1985. Odonata of the Tambopata Reserved Zone, Madre de Dios, Peru. Revista Peruana de Entomologia 27: 9-14.

Paulson, D.R., 2001a. Recent Odonata records from southern Florida - effects of global warming? International Journal of Odonatology 4: 57-69.

Paulson, D.R., 2001b. Orthemis schmidti is a widespread species. Argia 13 (3): 24-25.

Paulson, D.R., 2002a. Telebasis demerarum in Trinidad. Argia 14 (1): 9.

Paulson, D.R., 2002b. Odonata records from Nayarit and Sinaloa, Mexico, with comments on natural history and biogeography. Odonatologica 31: 359-370.

Paulson, D.R., 2003. Comments on the Erythrodiplax connata (Burmeister, 1839) group, with the elevation of E. fusca (Rambur, 1842), E. minuscula (Rambur, 1842), and E. basifusca (Calvert, 1895) to full species (Anisoptera: Libellulidae).

Bulletin of American Odonatology 6: 101-110.

Peters, G., 1988. Bionomische Beobachtungen und taxonomische Untersuchungen an Anisoptera von Cuba und dem östlichen Mexico. Deutsche Entomologische Zeitschrift, N.F. 35: 221-247.

Ramírez, A., 2000. Dragonflies and damselflies of Costarican cloud forests. In: Nadkarni, N.M. \& N.T. Wheelwright (eds) "Monteverde; ecology and conservation of a tropical cloud forest", Oxford University Press, Athens GA.

Ramírez, A. \& R. Novelo-Gutiérrez, 1999. The neotropical dragonfly genus Macrothemis: new larval descriptions and an evaluation of its generic status based on larval stages (Odonata, Libellulidae). Journal of the North American Benthological Society 18: 67-73.

Ramírez, A., D.R. Paulson \& C. Esquivel, 2000. Odonata of Costa Rica: diversity and checklist of species. Revista de Biologia Tropical 48: 247-254.

Rehn, A.C., 2003. Oligoclada teretidentis spec. nov. from eastern Ecuador (Anisoptera: Libellulidae). Odonatologica 32: 171-175.

Rodrigues Capitulo, A., 1999. Los macroinvertebrados como indicadores de calidad de ambientes lóticos en al área pampeana. Revista de la Sociedad Entomológica Argentina 58: 208-217. 
Rodrigues Capitulo, A., 2000. Population dynamics of larval stages of Tauriphila risi Martin and Erythemis attala (Selys) in Punta Lara gallery forest, Buenos Aires, Argentina (Anisoptera: Libellulidae). Odonatologica 29: 333-340.

Santos, T.C. \& J.M. Costa, 1999. Description of the last instar larva of Brechmorhoga travassosi Santos and comparison with other Brechmorhoga species (Anisoptera: Libellulidae). Odonatologica 28: 425-428.

Tennessen, K.J., 2000. Micrathyria sympriona spec. nov., a new dragonfly from Ecuador and Peru (Anisoptera: Libellulidae). Odonatologica 29: 67-73.

Tennessen, K.J., 2001. Coryphaeschna huaorania spec. nov. from central Ecuador with keys to all species in the genus (Odonata: Aeshnidae). International Journal of Odonatology 4: 71-81.

Tennessen, K.J., 2002. Telebasis simulata spec. nov. from South America, previously confused with T. sanguinalis Calvert (Zygoptera: Coenagrionidae). Odonatologica 31: 205-210.

Vick, G.S. \& D.G. Chelmick, 2001. A preliminary report on the odonate fauna of Guapi Açu, a nature reserve in the Atlantic coast forest of Brazil, with taxonomic notes and annotations. Opuscula Zoologica Fluminensia 200: 1-11.

von Ellenrieder, N., 1999. Description of the last instar of Aeshna (Hesperaeschna) cornigera planaltica (Odonata: Aeshnidae). Revista de la Sociedad Entomológica Argentina 58: 151-156. von Ellenrieder, N., 2000a. Species composition and temporal variation of odonate assemblages in the subtropical pampasic ecotone, Buenos Aires, Argentina. Odonatologica 29: 17-30. von Ellenrieder, N., 2000b. Aeshna tinti spec. nov. from Chile and redescription of $A$. elsia Calvert (Anisoptera: Aeshnidae). Odonatologica 29: 347-358.

von Ellenrieder, N., 2001a. A synopsis of the Patagonian species of the genus Aeshna Fabricius (Anisoptera: Aeshnidae). Odonatologica 30: 299-325.

von Ellenrieder, N., $2001 \mathrm{~b}$. The larvae of Patagonian species of the genus Aeshna Fabricius (Anisoptera: Aeshnidae). Odonatologica 30: 423-434.

von Ellenrieder, N., 2003a. A synopsis of the Neotropical species of 'Aeshna' Fabricius: the genus Rhionaeschna Förster (Odonata: Aeshnidae). Tijdschrift voor Entomologie 146: 67-207. von Ellenrieder, N., 2003b. Agnophilogenia Kennedy, 1940, a junior synonym of Philogenia Selys, 1862 (Zygoptera: Megapodagrionidae). Odonatologica 32: 387-391.

von Ellenrieder, N. \& J.M. Costa. 2002. Aeshna brasilienis sp. nov. (Odonata: Aeshnidae) from South and Southeastern Brazil, with a redescription of its larva.

Neotropical Entomology 31 (3): 1-8.

von Ellenrieder, N. \& R.W. Garrison, 2003. A synopsis of the genus Triacanthagyna.

International Journal of Odonatology 6: 147-184.

von Ellenrieder, N. \& J. Muzón, 1999. The Argentinean species of the genus Perithemis Hagen (Anisoptera: Libellulidae). Odonatologica 28: 385-398.

von Ellenrieder, N. \& J. Muzón, 2000. Description of the last instar larva of Erythrodiplax nigricans (Rambur) (Anisoptera: Libellulidae). Odonatologica 29: 267-272.

von Ellenrieder, N. \& J. Muzón, 2003. Description of the last larval instar of Aeshna (Marmaraeschna) pallipes Fraser, 1947 (Anisoptera: Aeshnidae). Odonatologica 32: 95-98.

Zloty, J. \& G. Pritchard, 2001. Cora chiribiquete spec. nov., a new damselfly species from Colombia (Zygoptera: Polythoridae). Odonatologica 30: 227-232. 